BISEI: Jurnal Bisnis dan Ekonomi Islam

Terakreditasi Nomor SK: B/4130/E5/.2.1/2019
Volume 06, Nomor 01, Juni 2021

E-ISSN 2541-2671. Hal. 13-25

\title{
Analisis Pengaruh Dana Pihak Ketiga (DPK), Non Performing Financing (NPF), BI Rate, dan Capital Adequacy Ratio (CAR) Terhadap Penyaluran Pembiayaan Pada Bank Umum Syariah di Indonesia Periode 2011- 2015
}

\author{
Sabarudin ${ }^{1 *}$, Aulia Nur Faizah ${ }^{2}$ \\ Jurusan Akuntansi, Fakultas Ilmu Sosial dan Ilmu Politik, Universitas Sembilanbelas \\ November Kolaka \\ Jln. Pemuda no 339 Kecamatan Kolaka, Kabupaten Kolaka 93517, Indonesia
}

\begin{abstract}
The aims of this research are to analyze the influence of Third Party Fund (DPK), Non Performing Financing (NPF), the BI Rate and Capital Adequacy Ratio (CAR) partially and simultaneously to the Distribution Financing Islamic Banks in Indonesia 2011-2015. The population in this research is all Islamic Banks in Indonesia in Period 2011-2015. This research uses purposive sampling method. The amount of sample in this research is 5 (five) Islamic Banks. The analysis model uses panel data reggresion model and analysis techniques techniques to the hypothesis uses Ftest,t-test, and R2 test.The results in this research in Third Party Fund (DPK) partially has positive andsignificant effect to Financing Distribution of Islamic Banks in Indonesia in Period 2011-2015, Ratio of Non-Performing Financing (NPF) partially negative and not significant to Distribution Financing Islamic Banks in Indonesia in Period 2011-2015, BI Rate is partially positive and significant to FinancingDistribution of Islamic Banks in Indonesia period 2011-2015, and the ratio of Capital Adequacy ratio (CAR) partially negative and significant to FinancingDistribution of Islamic Banks in Indonesia 20112015 , Simultaneously ThirdParty Fund (DPK), Non Performing Financing (NPF), the BI Rate and Capital Adequacy Ratio (CAR) have significant effect to Financing Distribution of Islamic Banks in Indonesia 2011-2015.
\end{abstract}

Keywords: Third Party Fund (DPK), Non Performing Financing (NPF), BI Rate, Capital Adequacy Ratio (CAR) and Distribution Financing

Paper type: Research Paper

*Corresponding author: sabarudincendana@rocketmail.com

Received: 11 Mei 2021, ; Accepted: 17 Juni 2021; Published: 25 Juni 2021

Cite this document: Sabarudin \& Faizah, A.N. (2021). Analisis Pengaruh Dana Pihak Ketiga (DPK), Non Performing Financing (NPF), BI Rate, dan Capital Adequacy Ratio (CAR) Terhadap Penyaluran Pembiayaan Pada Bank Umum Syariah di Indonesia Periode 2011-2015. BISEI: Jurnal Bisnis dan Ekonomi Islam, 6 (1), 13-25.

Copyright (C) 2021, BISEI: Jurnal Bisnis dan Ekonomi Islam http://ejournal.unhasy.ac.id/index.php/bisei 
Abstrak: Penelitian ini bertujuan untuk menganalisis pengaruh Dana Pihak Ketiga (DPK), Non Performing Financing (NPF), BI Rate dan Capital Adequacy Ratio (CAR) secara parsial dan simultan terhadap Penyaluran Pembiayaan Bank Umum Syariah di Indonesia periode 2011-2015. Populasi penelitian ini adalah seluruh Bank Umum Syariah di Indonesia periode 2011-2015. Penelitian ini menggunakan metode purposive sampling. Jumlah sampel dalam penelitian ini adalah 5 (lima) Bank Umum Syariah. Model analisis alam penelitian ini menggunakan model analisis regresi data panel dan teknik analisis uji $F$, uji t, dan uji R2. Hasil penelitian ini menunjukkan bahwa Dana Pihak Ketiga (DPK) secara parsial positif dan signifikan terhadap Penyaluran Pembiayaan Bank Umum Syariah di Indonesia periode 2011-2015, Rasio Non Performing Financing (NPF) secara parsial negatif dan tidak signifikan terhadap Penyaluran Pembiayaan Bank Umum Syariah di Indonesia periode 2011-2015, BI Rate secara parsial positif dan signifikan terhadap Penyaluran Pembiayaan Bank Umum Syariah di Indonesia periode 2011-2015, dan rasio Capital Adequacy Ratio (CAR) secara parsial negatif dan signifikan terhadap Penyaluran Pembiayaan Bank Umum Syariah di Indonesia periode 2011-2015. Secara simultan Dana Pihak Ketiga (DPK), Non Performing Financing (NPF), BI Rate dan Capital Adequacy Ratio (CAR) berpengaruh simultan terhadap Penyaluran Pembiayaan pada Bank Umum Syariah di Indonesia periode 2011-2015.

Kata kunci: Dana Pihak Ketiga (DPK), Non Performing Financing (NPF), BI Rate, Capital Adequacy Ratio (CAR) dan Penyaluran Pembiayaan

\section{Pendahuluan}

Bank merupakan badan usaha yang menghimpun dana dari masyarakat dalam bentuk simpanan dan menyalurkannya kepada masyarakat dalam bentuk kredit dan atau bentuk lainnya dalam rangka meningkatkan taraf hidup masyarakat Indonesia (UU No.21 Tahun 2008). Bank Syariah memiliki peranan sebagai lembaga perantara (intermediary) antara kelompok masyarakat atau unit-unit ekonomi yang mengalami kekurangan dana. Memperhatikan peranan bank syariah sebagai lembaga yang memiliki fungsi intermediasi dan bermanfaat bagi sektor riil. Oleh karena itu peningkatan peranan perbankan sangat diperlukan dalam rangka meningkatkan kesejahteraan masyarakat (Muhammad, 2005: 261).

Salah satu terkonsentrasinya usaha bank dalam menyalurkan pembiayaan merupakan sifat usaha bank sebagai lembaga intermediary antara surplus dengan defisit unit dan sumber utama bank yang berasal dari masyarakat dalam bentuk simpanan. (Siamat, 2005: 349). Penyaluran pembiayaan merupakan aktivitas bank yang paling utama dalam menghasilkan, tetapi risiko terbesar dalam bank juga bersumber dari penyaluran pembiayaan, sehingga dalam menyalurkan pembiayaan harus dikawal dengan manajemen risiko yang ketat.

Berdasarkan data Otoritas Jasa Keuangan (OJK), Pertumbuhan pembiayaan yang diberikan bank umum syariah (BUS) dan unit usaha syariah (UUS) sejak 2012 hingga 2015 terus menurun. Jika pada 2012 pembiayaan tumbuh 43,69\%, pada 2013 hanya tumbuh $24,82 \%$. Kondisi lebih buruk terjadi pada 2014, yaitu pembiayaan hanya

Copyright (C) 2021, BISEI: Jurnal Bisnis dan Ekonomi Islam

http://ejournal.unhasy.ac.id/index.php/bisei 
Sabrudin, Aulia Nur Faizah: Analisis Pengaruh Dana Pihak Ketiga (DPK), $\mid 15$ Non Performing Financing (NPF), BI Rate, dan Capital Adequacy Ratio (CAR) Terhadap Penyaluran Pembiayaan Pada Bank Umum Syariah di Indonesia Periode 2011-2015

tumbuh $8,23 \%$. per November 2015 , pembiayaan perbankan syariah secara year to date hanya tumbuh 3,37 \% (Infobank, 2016). pertumbuhan pembiayaan Bank Umum Syariah (BUS) dan Unit Usaha Syariah (UUS) dari tahun 2011 hingga tahun 2015 menunjukan pertumbuhan pembiayaan pada tahun 2011 sebesar 50,56 \% dan pada tahun 2012 mengalami penurunan menjadi 43,69\%, tahun 2013 sebesar 24,82\%, tahun 2014 hanya sebesar 7,51 \% dan pada tahun 2015 sebesar 6,85\%. (Statistik Perbankan Syariah OJK 2014-2015).

Keadaan ini menunjukkan bahwa perkembangan atau pertumbuhan perbankan syariah nasional terus mengalami penurunan sejak tahun 2011 serta perkembangan belum sesuai dengan peluang-peluang yang ada. Hal ini disebabkan oleh beberapa kendala yang ada dalam pengembangan perbankan syariah yakni dalam penyaluran pembiayaan. Keberhasilan bank syariah dalam menyalurkan pembiayaan dapat dipengaruhi dari beberapa faktor, baik internal maupun eksternal. Dengan demikian, dari faktor-faktor yang berpengaruh nantinya dapat dioptimalkan oleh bank syariah untuk mendorong peningkatan jumlah penyaluran pembiayaan pada bank syariah. Faktor-Faktor tersebut diantaranya adalah Dana Pihak Ketiga (DPK), Non Performing Financing (NPF), BI Rate, dan Capital Adequacy Ratio (CAR). Dalam hal ini penulis meneliti pembiayaan yang disalurkan pada Bank Syariah pada semua akad yang ada di Bank Umum Syariah di Indonesia.

Menurut Sentausa (2009) dalam Saryadi (2013), akibat tingginya NPL perbankanharus menyediakan pencadangan yang lebih besar sehingga pada akhirnya modal bank ikut terkikis. Padahal besaran modal sangat mempengaruhi besarnya ekspansi kredit. Besarnya NPL menjadi salah satu penyebab sulitnya perbankan dalam menyalurkan kredit. Dalam penelitian Caesarani (2011) NPF berpengaruh signifikan terhadap penyaluran pembiayaan. Hal ini berbeda dengan hasil penelitian Nasihin (2013) dan Kurniawati dan Zulfikar (2014) menyatakan bahwa NPF tidak berpengaruh terhadap pembiayaan berbasis bagi hasil.

Bank syariah dalam menetapkan besarnya keuntungan (return) yang diberikan kepada nasabah tergantung dari besarnya keuntungan yang diperoleh dari pembiayaan dengan prinsip syariah. Sedangkan bank konvensional menggunakan prinsip bunga dalam menentukan besarnya keutungan yang diperoleh nasabahnya. Perbedaan prinsip prinsip operasional ini seharusnya berdampak pada perbedaan dalam menetapkan besarnya cost of fund yang akan dibebankan kepada nasabah.

Cahyaning (2015), Putra dan Wirathi (2014) dan Astuti (2013) menyatakan bahwa BI Rate memiliki pengaruh negatif terhadap penyaluran pembiayaan. Sementara hasil berbeda dilakukan oleh penelitian Sari (2013) yang menyatakan bahwa BI Rate dalam jangka panjang memiliki pengaruh positif dan signifikan terhadap volume pembiayaan perbankan syariah. Bank Syariah dalam menyalurkan pembiayaan harus memperhatikan prinsip kehati-hatian. Karena bank syariah dalam menjalankan usahanya tidak bisa lepas dari peraturan Bank Indonesia. Prinsip kehati-hatian yang harus diperhatikan bank syariah adalah bank wajib menjaga kesehatannya agar bank dapat menjalankan fungsinya sebagai intermediary dan memberikan pelayanan yang baik kepada para nasabahnya. Bank tidak sehat akan membahayakan dirinya sendiri dan nasabah serta dapat menurunkan kepercayaan masyarakat kepada bank.

Selain itu, menurut Saryadi (2013) semakin tinggi nilai CAR maka semakin besar pula sumber daya finansial yang dapat digunakan untuk keperluan pengembangan usaha dan mengantisipasi potensi kerugian yang diakibatkan oleh penyaluran kredit. Yuwono dan Meiranto (2012) menyatakan bahwa kemampuan bank dalam menanggung risiko dari setiap kredit atau aktiva produktifnya dapat dilihat dari CAR pada suatu perusahaan tersebut. Jika CAR tinggi maka bank tersebut mampu membiayai kegiatan operasional 
dan memberikan kontribusi yang cukup besar bagi profitabilitasnya. Artinya, setiap pertambahan kegiatan bank yang mengakibatkan pertambahan profitabilitas harus diimbangi dengan pertambahan CAR sebesar yang telah ditetapkan oleh Bank Indonesia sehingga bank dapat menjalankan operasionalnya dengan baik dan aman.

Berdasarkan penelitian Ismaulandy (2014), Nasihin (2013) dan Triasdini (2010) menyatakan bahwa CAR memiliki pengaruh positif dan signifikan terhadap penyaluran kredit perbankan. Sementara hasil yang berbeda ditemukan dalam penelitian Astuti (2013) yang menyatakan CAR memiliki pengaruh negative terhadap penyaluran kredit. Bukti-bukti empiris yang ada menunjukkan bahwa terdapat banyak faktor yang mempengaruhi penyaluran pembiyaan namun demikian juga dapat diketahui bahwa terdapat ketidakselarasan dalam hasil-hasil penelitian yang telah dilakukan.

Berdasarkan uraian tersebut maka penulis tertarik untuk melakukan penelitian dengan judul: "Analisis Pengaruh Dana Pihak Ketiga (DPK), Non Performing Financing (NPF), BI Rate, dan Capital Adequacy Ratio (CAR) Terhadap Penyaluran Pembiayaan Bank Umum Syariah (BUS) di Indonesia Periode 2011-2015”.

\section{Metode Penelitian}

Kriteria yang digunakan dalam penentuan sampel penelitian meliputi:

1. Bank Umum Syariah di Indonesia yang operasionalnya telah spin off dari induk bank konvensional maupun sejak awal berdiri menggunakan prinsip syariah minimal 5 (lima) tahun.

2. Bank Umum Syariah di Indonesia yang telah membuat dan mempublikasikan laporan keuangan triwulan I-IV pada periode 2011-2015.

3. Bank Umum Syariah dapat memberikan pengungkapan informasi mengenai data yang dibutuhkan dalam penelitian. Total Sampel yang memenuhi adalah sebanyak 5 (lima) bank umum syariah yang memenuhi kriteria, yaitu:
a) PT. Panin Bank Syariah.
b) PT. Bank BNI Syariah
c) PT. Bank Syariah Mandiri.
d) PT. Bank BRI Syariah.
e) PT. Bank Muamalat Indonesia Tbk.

\section{Hipotesis Penelitian}

1. Diduga bahwa Dana Pihak Ketiga (DPK), BI Rate, Non Performing Financing (NPF) dan Capital Adequacy Ratio (CAR) secara simultan berpengaruh signifikan terhadap Penyaluran Pembiayaan Bank Umum Syariah (BUS) di Indonesia periode 20112015.

2. Diduga bahwa variabel Dana Pihak Ketiga (DPK) secara parsial berpengaruh signifikan terhadap Penyaluran Pembiayaan Bank Umum Syariah (BUS) di Indonesia periode 2011-2015.

3. Diduga bahwa variabel Non Performing Financing (NPF) secara parsial berpengaruh signifikan terhadap Penyaluran Pembiayaan Bank Umum Syariah (BUS) di Indonesia periode 2011-2015.

4. Diduga bahwa variabel BI Rate secara parsial berpengaruh signifikan terhadap Penyaluran Pembiayaan Bank Umum Syariah (BUS) di Indonesia Periode 20112015.

5. Diduga bahwa variabel Capital Adequacy Ratio (CAR) secara parsial berpengaruh signifikan terhadap Penyaluran Pembiayaan Bank Umum Syariah (BUS) di Indonesia Periode 2011-2015.

Copyright (C) 2021, BISEI: Jurnal Bisnis dan Ekonomi Islam http://ejournal.unhasy.ac.id/index.php/bisei 
Sabrudin, Aulia Nur Faizah: Analisis Pengaruh Dana Pihak Ketiga (DPK), Non Performing Financing (NPF), BI Rate, dan Capital Adequacy Ratio (CAR) Terhadap Penyaluran Pembiayaan Pada Bank Umum Syariah di Indonesia Periode 2011-2015

\section{Pengumpulan Data}

Metode pengumpulan data yang digunakan dalam penelitian ini dengan studi pustaka dari Statistik Perbankan Syariah, situs www.bi.go.id, www.ojk.go.id, www.syariahmandiri.co.id, www.bankmuamalat.co.id/, www.bnisyariah.co.id/, www.brisyariah.co.id dan www.paninbanksyariah.co.id Selanjutnya melakukan eksplorasi laporan-laporan keuangan triwulan dari masing-masing bank meliputi neraca dan data rasio keuangan yang diterbitkan oleh masing-masing bank umum syariah dan BI Rate pada situs Bank Indonesia yang menjadi sampel.

\section{Variabel Operasional}

1. Variabel Dependent

Variabel dependen dalam penelitian ini adalah Penyaluran Pembiayaan. Menurut Muhammad (2005: 17), penyaluran pembiayaan adalah pendanaan yang diberikan oleh suatu pihak kepada pihak lain untuk mendukung investasi yang telah direncanakan, baik dilakukan sendiri maupun lembaga, kepada pihak yang terkait dengan bank maupun dengan pihak yang tidak terkait dengan bank, baik dalam rupiah maupun dalam valuta asing. Ukuran variabel ini adalah rupiah dan skala datanya adalah rasio.

2. Variabel Independent

a. Dana Pihak Ketiga (DPK)

Dana Pihak Ketiga (DPK) adalah sumber dana terpenting bagi kegiatan operasi bank dan merupakan ukuran keberhasilan bank jika mampu membiayai operasinya dari sumber dana ini (Kasmir,2010:67). Menurut Ismail (2010:43), sumber dana yang berasal dari Dana Pihak Ketiga antara lain: dalam bentuk yang dirumuskan sebagai berikut:

\section{Dana Pihak Ketiga $(D P K)=$ Giro + Tabungan + Deposito}

b. Non Performing Financing (NPF)

Non Performing Financing (NPF) merupakan perbandingan antara pembiayaan bermasalah (KL, D, M) terhadap total pembiayaan (Lampiran SE BI Nomor 13/24/DPNP 25 Oktober 2011). NPF digunakan untuk mengukur tingkat permasalahan pembiayaan yang dihadapi oleh bank. Semakin tinggi rasio ini menunjukkan kualitas pembiayaan bank syariah semakin buruk. NPF diukur dengan rumus sebagai berikut:

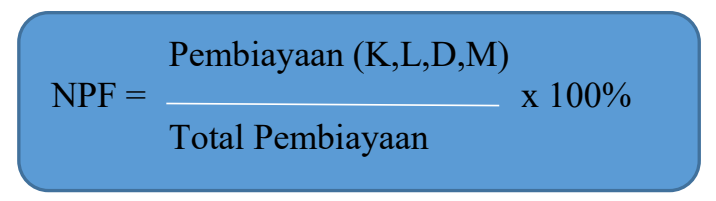

c. BI Rate 
BI Rate adalah suku bunga kebijakan yang mencerminkan sikap atau stance kebijakan moneter yang ditetapkan oleh Bank Indonesia dan diumumkan kepada publik. BI Rate diumumkan oleh Dewan Gubernur Bank Indonesia setiap Rapat Dewan Gubernur bulanan dan diimplementasikan pada operasi moneter yang dilakukan Bank Indonesia melalui pengelolaan likuiditas (liquidity management) di pasar uang untuk mencapai sasaran operasional kebijakan moneter. Sasaran operasional kebijakan moneter dicerminkan pada perkembangan suku bunga Pasar Uang antar Bank Overninght (PAUB O/N). Pergerakan di suku bunga PUAB ini akan diikuti oleh perkembanngan di suku bunga deposito, dan pada gilirannya suku bunga kredit perbankan. Perbankan di Indonesia dalam menetapkan suku bunga simpanan dan suku bunga pinjaman mengacu pada ketetapan BI Rate termasuk bank syariah dalam menetapkan margin dan rate bagi hasil juga mengacu pada BI Rate yang ditetapkan oleh Bank Indonesia (www.bi.go.id).

d. Capital Adequacy Ratio (CAR)

Capital Adequacy Ratio (CAR) adalah rasio yang memperlihatkan seberapa jauh seluruh aktiva bank yang mengandung risiko (kredit, penyertaan, surat berharga, tagihan pada bank lain) ikut dibiayai dari dana modal sendiri bank disamping memperoleh dana-dana dari sumbersumber diluar bank. Semakin besar rasio tersebut, maka semakin baik posisi modal sebuah bank (Dendawijaya, 2005 :112). Menurut Peraturan Bank Indonesia No.15/12/PBI/2013 dijelaskan bahwa Capital Adequacy Ratio (CAR) secara matematis dirumuskan sebagai berikut:

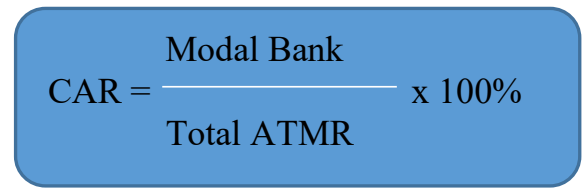

\section{Model Analisis Data}

Model yang digunakan dalam menganalisis data dalam penelitian ini menggunakan analisis regresi data panel. Regresi dengan menggunakan data panel disebut model regresi data pan 
Sabrudin, Aulia Nur Faizah: Analisis Pengaruh Dana Pihak Ketiga (DPK), 19

Non Performing Financing (NPF), BI Rate, dan Capital Adequacy Ratio

(CAR) Terhadap Penyaluran Pembiayaan Pada Bank Umum Syariah di Indonesia Periode 2011-2015

\section{Hasil dan Pembahasan}

1. Pengaruh Simultan Variabel-Variabel Dana Pihak Ketiga (DPK), Non Performing Financing (NPF), BI Rate, dan Capital Adequacy Ratio (CAR) terhadap Penyaluran pembiayaan Bank Umum Syariah (BUS) di indonesia periode 2011-2015.

Hasil dari pengujian hipotesis 1 , menunjukan nilai Fhitung $=92.52711$ lebih besar dari Ftabel 2.69 atau $p=0.000000<0.05$. Dengan demikian, dapat diketahui bahwa Dana Pihak Ketiga (DPK), Non Performing Financing (NPF), BI Rate, dan Capital Adequacy Ratio (CAR) secara simultan berpengaruh signifikan terhadap Penyaluran pembiayaan Bank Umum Syariah (BUS) di indonesia periode 20112015 Keadaan ini menunjukkan bahwa penggabungan variabel-variabel DPK, NPF, BI Rate dan CAR relevan digunakan untuk memprediksi Penyaluran pembiayaan Bank Umum Syariah (BUS) di indonesia periode 2011-2015.

Disisi lain koefisien derterminasi (Adjusted R2 ) menunjukan hasil R2 $=0.787146$ atau $78.7146 \%$. Hal ini menunjukan bahwa Variabel independen berkontribusi dalam menerangkan variabel dependen sebesar 0.787146 . Hal ini juga menunjukkan bahwa kontribusi variabel DPK, NPF, BI Rate dan CAR dalam mempengaruhi Penyaluran pembiayaan sebesar $78.7146 \%$ sementara sisanya $21.2856 \%$ dipengaruhi oleh variabel lain yang tidak diteliti dalam penelitian ini.

\section{Pengaruh Secara Parsial Variabel Dana Pihak Ketiga (DPK) terhadap}

\section{Penyaluran Pembiayaan}

Bedasarkan hasil uji t, diketahui bahwa nilai thitung X1 $=8.179163$ lebih besar dari ttabel $=1.98$ atau $\mathrm{p}=0.000<0.05$. Dengan demikian, hipotesis 2 yang menyatakan Diduga variabel Dana Pihak Ketiga (DPK) secara parsial berpengaruh signifikan terhadap Penyaluran pembiayaan Bank Umum Syariah (BUS) di indonesia periode 2011-2015"dinyatakan diterima.

Hasil ini mendukung teori yang dikemukakan oleh Kasmir (2010: 67), bahwa Dana Pihak Ketiga (DPK) merupakan sumber dana terpenting bagi kegiatan operasi bank dan merupakan ukuran keberhasilan bank jika mampu membiayai operasinya dari sumber dana ini. Salah satu sumber dana yang dapat digunakan untuk penyaluran pembiayaan adalah simpanan, sehingga semakin besar sumber dana (simpanan) yang ada di dalam bank, maka akan dapat menyalurkan pembiayaan semakin besar pula. Semakin meningkatnya pertumbuhan Dana Pihak Ketiga (DPK) akan mengakibatkan meningkatnya pertumbuhan pembiayaan pada perbankan syariah begitu pula sebaliknya. Apabila bank syariah mengalami penurunan Dana Pihak Ketiga maka penyaluran pembiayaan juga mengalami penurunan. Hasil penelitian ini mendukung hasil penelitian sebelumnya yang dilakukan oleh Sa'adah (2015), Cahyaning (2015), Ismaulandy (2014), Sari (2013), Nasihin (2013), Yuwono dan Meiranto (2012), Caesarani (2011) dan Khotimah (2009) yang menyatakan bahwa Dana Pihak Ketiga (DPK) secara parsial berpengaruh positif dan signifikan terhadap penyaluran pembiayaan. 


\section{Pengaruh Secara Parsial Variabel Non Performing Financing (NPF) terhadap Penyaluran Pembiayaan.}

Bedasarkan hasil uji t, diketahui bahwa nilai thitung X2 $=|1.398043|$ lebih kecil dari ttabel $=1.98$ atau $\mathrm{p}=0.1654>0.05$. Dengan demikian, hipotesis 3 yang menyatakan "Diduga variabel Non Performing Financing (NPF) secara parsial berpengaruh signifikan terhadap Penyaluran pembiayaan Bank Umum Syariah (BUS) di indonesia periode 2011-2015", dinyatakan ditolak.

Semula diduga bahwa Non Performing Financing (NPF) secara parsial berpengaruh signifikan terhadap Penyaluran Pembiayaan pada Bank Umum Syariah di Indonesia periode 2011-2015. Hasil penelitian ini sejalan dengan hasil penelitian Caesarani (2011), Siswati (2013), Nasihin (2013) dan Cahyaning (2015) yang menunjukkan bahwa NPF mempunyai pengaruh signifikan terhadap penyaluran pembiayaan. Namun berdasarkan hasil pengujian hipotesis 3 , NPF berpengaruh negatif dan tidak signifikan terhadap penyaluran pembiayaan.

Semakin tingginya pembiayaan bermasalah dapat menimbulkan keengganan bank untuk menyalurkan pembiayaan. Kegiatan penyaluran kredit atau pembiayaan ini sangat mengandung risiko yang dapat mempengaruhi kesehatan dan kelangsungan hidup bank. (Mukhlis,2011:131).

Tingkat signifikansi yang lebih dari 0,05 menunjukkan bahwa pengaruh variabel NPF terhadap pembiayaan berpengaruh jika tingkat signifikansi lebih dari 0,05 atau sebesar $5 \%$. Hasil penelitian ini menunjukkan bahwa nilai ratarata NPF terhadap pembiayaan hanya sebesar 3,0289 \% sehingga dapat disimpulkan bahwa NPF memiliki pengaruh yang kecil terhadap pembiayaan. Hal ini dapat terjadi karena, nilai rata-rata NPF yang sebesar 3,0289 \% masih dibawah $5 \%$ sesuai ketentuan yang diterapkan oleh Otoritas Jasa Keungan (OJK). Sehingga kenaikan atau penurunan tingkat NPF tidak mempunyai pengaruh secara langsung terhadap besarnya pembiayaan yang disalurkan.

Menurut Rivai dan Arifin (2010:799) dalam penyaluran pembiayaan, bank Islam akan memperhatikan batas-batas pemberian pembiayaan. Hal penting yang perlu diperhatikan adalah ketentuan financing to deposit ratio yang telah ditetapkan oleh Bank Indonesia tidak boleh melebihi $110 \%$. Yang berarti bank boleh memberi kredit atau pembiaayan melebihi jumlah dana pihak ketiga yang dihimpun asalkan tidak melebihi $110 \%$ (Rivai dan Arifin, 2010 :785). Dengan demikian, maka NPF tidak menjadi tolok ukur besarnya pembiayaan yang disalurkan.

4. Pengaruh Secara Parsial Variabel BI Rate terhadap Penyaluran Pembiayaan.

Bedasarkan hasil uji t, diketahui bahwa nilai thitung X3 $=5.179304$ lebih besar dari ttabel $=1.98$ atau $\mathrm{p}=0.0000<0.05$. Dengan demikian, 
Sabrudin, Aulia Nur Faizah: Analisis Pengaruh Dana Pihak Ketiga (DPK), $\mid 21$

Non Performing Financing (NPF), BI Rate, dan Capital Adequacy Ratio

(CAR) Terhadap Penyaluran Pembiayaan Pada Bank Umum Syariah di Indonesia Periode 2011-2015

hipotesis 4 yang menyatakan "Diduga variabel BI Rate secara parsial berpengaruh signifikan terhadap Penyaluran pembiayaan Bank Umum Syariah (BUS) di indonesia periode 2011-2015", dinyatakan diterima.

Hal ini sejalan dengan teori yang disampaikan oleh Bank Indonesia yang menyatakan bahwa BI Rate adalah suku bunga kebijakan yang mencerminkan sikap atau stance kebijakan moneter yang ditetapkan kepada publik. BI Rate diumumkan oleh Dewan Gubernur Bank Indonesia setiap Rapat Dewan Gubernur bulanan dan diimplementasikan pada operasi moneter yang dilakukan Bank Indonesia melalui pengelolaan likuiditas (liquidity management) di pasar uang untuk mencapai sasaran operasional kebijakan moneter.

Sasaran operasional kebijakan moneter dicerminkan pada perkembangan suku bunga Pasar Uang antar Bank Overninght (PAUB O/N). Pergerakan di suku bunga PUAB ini akan diikuti oleh perkembanngan di suku bunga deposito, dan pada gilirannya suku bunga kredit perbankan (www.bi.go.id). Perbankan di Indonesia dalam menetapkan suku bunga simpanan dan suku bunga pinjaman mengacu pada ketetapan BI Rate termasuk bank syariah dalam menetapkan margin dan rate bagi hasil juga mengacu pada BI Rate yang ditetapkan oleh Bank Indonesia.

Semula diduga bahwa BI Rate memiliki arah pengaruh negatif terhadap penyaluran pembiayaan, hal ini akan berpengaruh terhadap pembiayaan bank syariah karena kreditur akan enggan mengambil pembiayaan pada bank syariah apabila terjadi kenaikan BI Rate yang diikuti dengan naiknya tingkat margin dan rate bagi hasil pada pembiayaan. Sehingga semakin tinggi nilai BI Rate maka akan menurunkan jumlah pembiayaan yang disalurkan begitupula sebaliknya. Namun, berdasarkan hasil pengujian hipotesis 4, BI Rate berpengaruh positif terhadap penyaluran pembiayaan. Nilai koefisien yang positif dan signifikan menunjukkan bahwa meskipun tingkat BI Rate yang tinggi namun tidak mempengaruhi jumlah permintaan pembiayaan pada Bank Umum Syariah di Indonesia periode 2011-2015.

Hal tersebut dikarenakan ketika BI Rate di naikkan oleh Bank Indonesia (BI), pihak bank umum syariah tidak langsung merespon kebijakan tersebut. Ketika BI Rate dinaikkan, bank umum syariah masih menggunakan BI Rate sebelumnya sebagai acuan margin/bagi hasil pinjaman maupun simpanan bank. Jadi dapat disimpulkan ketika BI Rate dinaikkan hal tersebut tidak langsung merespon margin/bagi hasil bank umum syariah, karena akan terjadi masa transisi dimana pengaruh dari kebijakan Bank Indonesia (BI) tersebut tidak bisa langsung dirasakan dampaknya dalam jangka waktu dekat. Hasil penelitian ini mendukung penelitian sebelumnya yang dilakukan oleh Sari 
(2013) yang menyatakan BI Rate memiliki pengaruh positif dan signifikan terhadap penyaluran pembiayaan.

\section{Pengaruh Secara Parsial Variabel Capital Adequacy Ratio (CAR) terhadap Penyaluran Pembiayaan}

Berdasarkan hasil uji t, diketahui bahwa nilai thitung X4 $=|5.953701|$ lebih besar dari ttabel $=1.98$ atau $\mathrm{p}=0.000<0.05$. Dengan demikian, hipotesis 5 yang menyatakan "Diduga variabel Capital Adequacy Ratio (CAR) secara parsial berpengaruh signifikan terhadap Penyaluran pembiayaan Bank Umum Syariah (BUS) di indonesia periode 2011-2015", dinyatakan diterima.

Hasil penelitian ini mendukung teori yang dikemukakan Dendawijaya (2005:112) yang berpendapat bahwa Capital Adequacy Ratio (CAR) adalah rasio kinerja bank untuk mengukur kecukupan modal yang dimiliki bank untuk menunjang aktiva yang mengandung atau menghasilkan risiko, misalnya pada penyaluran pembiayaan.

Semakin tinggi Capital Adequacy Ratio (CAR) maka semakin besar pula sumber daya financial yang dpat digunakan untuk keperluan pengembangan usaha dan mengantisipasi potensi kerugian yang diakibatkan oleh penyaluran kredit (Saryadi,2013). Capital Adequacy Ratio (CAR) merupakan modal dibandingkan aktiva yang mengandung risiko atau risiko kecukupan modal minimum dengan memperhitungkan risiko pasar (market risk).

Semula diduga Capital Adequacy Ratio (CAR) memiliki arah pengaruh positif tehadap penyaluran pembiayaan Namun, berdasarkan hasil pengujian hipotesis 5 Capital Adequacy Ratio (CAR) berpengaruh negatif terhadap penyaluran pembiayaan. Nilai koefisien yang negatif dan signifikan dari hasil penelitian ini mengindikasikan bahwa peningkatan atau penurunan Capital Adequacy Ratio (CAR) selama periode penelitian mempengaruhi penyaluran pembiayaan. Semakin besar CAR maka semakin tinggi kemampuan permodalan bank dalam menjaga kemungkinan timbulnya risiko kerugian kegiatan usahanya namun belum tentu secara nyata berpengaruh terhadap peningkatan penyaluran pembiayaan Bank Umum Syariah di Indonesia. Disisi lain, CAR Bank Umum Syariah yang tinggi dapat mengurangi kemampuan bank dalam melakukan ekspansi usahanya seperti penyaluran pembiayaan karena semakin besarnya cadangan modal yang digunakan untuk menutupi risiko kerugian. Rata - rata CAR Bank Umum Syariah di Indonesia berada pada kisaran yang cukup tinggi yakni $19.37 \%$, diatas ketentuan minimal yang disyaratkan oleh Bank Indonesia sebesar $8 \%$.

Semakin besar rasio kecukupan modal suatu bank diatas angka minimum menunjukkan bahwa bank memiliki dana yang belum disalurkan melalui aktiva produktif yang mengandung risiko, salah satunya pembiayaan. Apabila pembiayaan yang disalurkan oleh bank semakin besar, maka akan mengakibatkan ATMR bank semakin besar yang mengakibatkan rasio CAR semakin kecil hal ini juga merupakan upaya Bank Umum Syariah dalam menetapkan modal minimum lebih besar untuk menghadapi potensi kerugian yang membutuhkan modal lebih besar sebagaimana dimaksud pada ayat 3 (tiga) Peraturan Otoritas Jasa Keuangan 
Sabrudin, Aulia Nur Faizah: Analisis Pengaruh Dana Pihak Ketiga (DPK), 23

Non Performing Financing (NPF), BI Rate, dan Capital Adequacy Ratio

(CAR) Terhadap Penyaluran Pembiayaan Pada Bank Umum Syariah di Indonesia Periode 2011-2015

No.21/PBJOK.03/2014 tentang kewajiban penyediaan modal minimum bank umum syariah.

Hasil penelitian ini mendukung penelitian sebelumnya yang dilakukan oleh Ismaulandy (2014), Nasihin (2013) dan Sari (2013) yang menyatakan bahwa Capital Adequacy Ratio (CAR) berpengaruh signifikan terhadap penyaluran pembiayaan dan hasil penelitian dari Katmas (2014) sejalan dengan hasil penelitian ini yang menyatakan bahwa Capital Adequacy Ratio (CAR) berpengaruh negatif dan signifikan terhadap penyaluran pembiayaan.

\section{Penutup}

\section{Kesimpulan}

1. Dana Pihak Ketiga (DPK), Non Performing Financing (NPF), BI Rate, dan Capital Adequacy Ratio (CAR) secara simultan berpengaruh signifikan terhadap Penyaluran pembiayaan Bank Umum Syariah (BUS) di Indonesia periode 2011-2015.

2. Dana Pihak Ketiga (DPK) secara parsial berpengaruh signifikan terhadap Penyaluran pembiayaan Bank Umum Syariah (BUS) di Indonesia periode 2011-2015.

3. Non Performing Financing (NPF) secara parsial berpengaruh tidak signifikan terhadap Penyaluran pembiayaan Bank Umum Syariah (BUS) di Indonesia periode 2011-2015.

4. BI Rate secara parsial berpengaruh signifikan terhadap Penyaluran pembiayaan Bank Umum Syariah (BUS) di Indonesia periode 2011-2015.

5. Capital Adequacy Ratio (CAR) secara parsial berpengaruh signifikan terhadap Penyaluran pembiayaan Bank Umum Syariah (BUS) di Indonesia periode 20112015.

\section{Referensi}

Ajija, Shochrul Rohmatul. 2011. Cara Cerdas Menguasai Eviews. Jakarta: Salemba Empat.

Astuti, Ati. 2013. Pengaruh Inflasi, BI Rate, Dana Pihak Ketiga (DPK), Non Performing Loan (NPL) dan Capital Adequacy Ratio (CAR) terhadap penyaluran kredit pada 10 bank terbesar di Indonesia berdasarkan kredit..Skripsi. Universitas Islam Negeri Syarif Hidayatullah Yogyakarta.

Batati, Firdah Al. 2011. Analisis Pengaruh Dana Pihak Ketiga (DPK), Non Performing Financing (NPF), dan Sertifikat Bank Indonesia Syariah (SBIS) Terhadap Jumlah Pembiyaan Perbankan Syariah di Indonesia Periode Januari 2004-April 2011. Skripsi. Semarang: Politeknik Negeri Semarang.

Caesarani, Asri Puri. 2011. Analisis Pengaruh Dana Pihak Ketiga (DPK), Sertifikat Bank Indonesia (SBIS) dan Pembiayaan Bermasalah Terhadap Penyaluran Pembiayaan Pada Bank Umum Syariah di Indonesia Periode 2006-2010. Skripsi. Semarang: Politeknik Negeri Semarang.

Cahyaning, Wanda Annisa. 2015. Analisis Pengaruh Faktor Eksternal dan Internal terhadap Penyaluran Kredit Perbankan di Indonesia. Jurnal Ilmiah Publikasi Universitas Brawijaya Malang 
Dendawijaya, Lukman. 2003. Manajemen Perbankan. Cetakan Pertama. Jakarta:Ghalia Indonesia.

Departemen Agama. Al-Qur'an dan Terjemahannya. 1996. Semarang: CV Toha Putra.

Hasanah, Siti. 2011. Fiqih Muamalah Teori dan Terapan. Semarang: Penerbit Polines.

Ismaulandy, Wildan. 2014. Analisis Variabel DPK, CAR, NPL, LDR, ROA, GWM dan Inflasi terhadap Penyaluran Kredit Investasi pada Bank BUMN periode 2005-2013. Jurnal Ilmiah Publikasi Universitas Brawijaya Malang.

Kasmir. 2010. Bank dan Lembaga Keuangan Lainnya. Edisi 6. Jakarta: PT Raja Grafindo Persada Jakarta.

Khatimah,Husnul.2009..Analisis Faktor-Faktor yang Mempengaruhi Penyaluran Dana Perbankan Syariah di Indonesia Sebelum dan Sesudah Kebijakan Akselarasi Perbankan Syariah Tahun 2007/2008. Jurnal Optimal. Vol.3 No.1.

Kurniawati, Agustina dan Zulfikar. 2014. Analisis Faktor-Faktor Yang Mempengaruhi Volume Pembiayaan Berbasis Bagi Hasil Pada Bank Umum Syariah di Indonesia. Seminar Nasional dan Call For Paper FEB UMS 25 Juni.

Nasihin. 2013. Pengaruh Faktor Internal Bank Terhadap Volume Pembiyaan Pada Bank Syariah di Indonesia. Skripsi. Universitas Islam Negeri Sunan Kalijaga.

Romansyah, Dadang. 2009. Penentuan Rate Bagi Hasil Deposito Mudharabah Bank Syariah di Indonesia. Islamic Banking Research. Jakarta: Universitas Paramadina

Rivai, Veithzal. 2007. Bank and Financial Institute Management. Jakarta: PT. RajaGrafindo Persada.

Rizal, Veithzal dan Arivin, Arviyan. 2010. Islamic Banking Sebuah Teori, Konsep dan Aplikasi. Jakarta: PT Bumi Aksara.

Sa'adah Iqomatus. 2015. Analisis Pengaruh Dana Pihak Ketiga (DPK), Capital Adequacy Ratio (CAR), BI Rate dan Inflasi Terhadap penyaluran pembiayaan pada Bank Umum Syariah di Indonesia Periode 2008-2014. Skripsi. Politeknik Negeri Semarang.

Satria, Dias dan Rangga Bagus Subegti. 2010. Determinasi Penyaluran Kredit Bank Umum di Indonesia Periode 2006-2009. Jurnal Keuangan dan Perbankan, Volume 14, Nomor 3.

Sari, Gredy Normala. 2013. Faktor-Faktor yang Mempengaruhi Penyaluran Kredit Bank Umum di Indonesia periode 2008-2012. JURNAL EMBA. Vol.1 No.3. September. Hal 931-941.

SE BI No. 9/24/DPbs/2007. 2007. Surat Edaran Bank Indonesia No. 9/24/DPbs/2007 tentang Sistem Penilaian Tingkat Kesehatan Bank Umum Berdasarkan Prinsip Syariah. Jakarta: Bank Indonesia.

Sugiyono. 2011. Metode Penelitian Pendidikan (Pendekatan Kuantitatif, Kualitatif dan $R \& D)$. Bandung: Alfabeta. 
Sabrudin, Aulia Nur Faizah: Analisis Pengaruh Dana Pihak Ketiga (DPK), Non Performing Financing (NPF), BI Rate, dan Capital Adequacy Ratio (CAR) Terhadap Penyaluran Pembiayaan Pada Bank Umum Syariah di Indonesia Periode 2011-2015

Susanti, Iin Puji. 2014. Analisis Pengaruh Dana Pihak Ketiga (DPK), Non Performing Financing (NPF) dan Capital Adequacy Ratio (CAR), Terhadap penyaluran pembiayaan pada Bank Umum Syariah di Indonesia Periode 2009-2013. Skripsi: Politeknik Negeri Semarang.

Surat Edaran Bank Indonesia No.6/23/DPNP tanggal 31 Mei 2014 tentang Capital Adequacy Ratio.

Surat Edaran Bank Indonesia No.13/24/DPNP tanggal 25 Oktober 2011 tentang Penilaian Tingkat Kesehatan Bank Umum.

Surat Edaran Peraturan Otoritas Jasa Keuangan No21./POJK.03/2014 tentang Kewajiban Penyediaan Modal Minimum Bank Syariah. Jakarta: Bank Indonesia.

Triasdini, Himaniar. 2010. Pengaruh CAR, NPL, dan ROA terhadap Penyaluran Kredit Modal Kerja. Skripsi. Universitas Diponegoro Semarang.

Wangsawidjaja. 2012. Pembiayaan Bank Syariah. Jakarta: PT Gramedia Pustaka Utama.

Widarjono, Agus. 2009. Ekonometrika Pengantar dan Aplikasinya. Yogyakarta: EKONISIA.

Wiroso. 2005. Penghimpunan Dana dan Distribusi Hasil Usaha bank Syariah. Jakarta: PT. Gramedia Widiasarana Indonesia.

Yuwono, Febri Amithya dan Wahyu Meiranto. 2012. Analisis Pengaruh DPK, LDR, CAR, NPL, ROA dan Sertifikat Bank Indonesia terhadap Jurnal Penyaluran Kredit. 